\title{
PENGARUH PRODUCT USABILITY DAN CASHBACK PROMOTION TERHADAP BRAND LOYALTY LAYANAN DIGITAL WALLET DI INDONESIA
}

\author{
I. G. W. S. C. Putra \\ Jurusan Bisnis Digital, Universitas Bunda Mulia, Jakarta Utara \\ e-mail: iputra@bundamulia.ac.id
}

\begin{abstract}
Abstrak
Digital Wallet merupakan sebuah teknologi finansial yang sedang populer digunakan oleh masyarakat di Indonesia. Namun, mayoritas pengguna layanan ini kurang loyal karena sering menggunakan lebih dari 1 aplikasi. Dalam penelitian ini penulis melakukan analisa mengenai pengaruh faktor product usability dan cashback promotion terhadap brand loyalty dari pengguna layanan digital wallet,. Hasil penelitian ini menunjukan bahwa faktor product usability dan cashback promotion memiliki pengaruh yang signifikan positif kepada brand loyalty pengguna layanan digital wallet baik secara simultan dan secara parsial. Hal ini membuktikan bahwa kedua faktor ini menjadi faktor penentu seberapa loyal masyarakat terhadap sebuah brand dari layanan digital wallet.
\end{abstract}

Kata kunci: Product Usability, Cashback Promotion, Brand Loyalty, Digital Wallet, Fintech

\begin{abstract}
Digital Wallet was a financial technology that was currently being used by people in Indonesia. However, the majority of users of this service were less loyal because they often use more than 1 application. In this study the authors analyzed the influence of product usability and cashback promotion factors on brand loyalty of digital wallet service users. The results of this study indicate that the product usability and cashback promotion factors have a significant positive effect on brand loyalty of digital wallet service users both simultaneously and partially. This proves that these two factors are determinants of how loyal the community is to a brand of digital wallet services.
\end{abstract}

Keywords : Brand Loyalty, Cashback Promotion, Digital Wallet, Fintech, Product Usability

\section{Pendahuluan}

Pada era industri 4.0, segala proses interaksi fisik mulai mengalami peralihan ke arah digital karena munculnya istilah cyber physical system yang pada intinya adalah mengubah interaksi digital menjadi seolah-olah seperti interaksi secara fisik karena adanya perangkat fisik yang terhubung melalui internet (Refsdal, 2015). Saat ini berbagai perusahaan berlomba-lomba untuk melakukan digitalisasi sehingga akibatnya segala proses transaksi bisnis mulai beralih ke transaksi digital. Kemunculan berbagai layanan transaksi secara digital ini mendorong munculnya berbagai metode pembayaran baru yang berlahan mulai menggantikan metode pembayaran konvensional yang biasanya menggunakan uang tunai atau kartu kredit/debit (Tazkiyyaturrohmah, 2018). Dalam kasus ini, metode pembayaran yang sedang populer di Indonesia saat ini adalah pembayaran dengan uang elektronik atau sering disebut sebagai digital wallet (Dikdik, 2019).

Digital wallet merupakan salah satu financial technology (fintech) yang pada dasarnya memiliki tujuan untuk mengurangi penggunaan uang tunai dengan menyediakan suatu platform pembayaran yang dikombinasikan dengan mobile technology untuk dapat menciptakan kemudahan dalam bertransaksi. Untuk pembayaran produk / layanan, masingmasing layanan digital wallet memiliki cara pembayaran yang berbeda-beda bergantung pada aplikasinya masing-masing. Teknologi yang sering digunakan adalah melalui scan QR code atau melakukan koneksi antara aplikasi pelanggan dengan aplikasi merchant via internet (Dikdik, 2019). Dengan kemudahan cara bertransaksi ini, pengguna tidak perlu repot membawa uang tunai atau kartu debit karena segala pembayaran dapat menggunakan satu perangkat saja. 
Di Indonesia, layanan digital wallet juga seringkali di identikkan dengan strategi promosi besar-besaran untuk mendorong masyarakat untuk menggunakan layanannya. Gencarnya promosi yang dilakukan melalui penawaran berbentuk cashback cukup efektif dalam mendorong naiknya jumlah pengguna layanan ini di Indonesia.

Jika melihat ke belakang, terdapat beberapa riset sebelumnya yang pernah membahas layanan digital wallet di Indonesia. Seperti penelitian yang dilakukan oleh (Haidari, 2018) yang membahas analisa faktor trust, perceived usefulness dan perceived risk dalam penggunaan GOPAY. Penelitian ini memperoleh hasil bahwa hanyalah faktor trust dan perceived usefulness yang berpengaruh signifikan positif terhadap penggunaan GO-PAY. Namun faktor perceived usefulness ini memang lebih bersifat subjektif ke masing-masing pengguna sehingga diperlukan penelitian lebih lanjut menggunakan faktor lain yang lebih objektif misalkan seperti faktor product usability.

Penelitian lain yang berkaitan dengan layanan digital wallet adalah penelitian yang dilakukan oleh (Oktaviani, 2019) yang membahas pengaruh kepuasan konsumen terhadap komitmen pelanggan dan e-WOM pada pengguna OVO. Penelitian ini memperoleh hasil bahwa kepuasan konsumen berpengaruh signifikan positif terhadap komitmen pelanggan dan e-WOM. Namun, walaupun kepuasan konsumen akan meningkatkan komitmen mereka dalam menggunakan OVO, keinginan mereka dalam menggunakan layanan digital wallet lainnya selain OVO (brand loyalty) masih patut dipertanyakan.

Sebelum penelitian dilakukan, penulis terlebih dahulu melakukan survei awal (preliminary research) kepada 61 responden pengguna layanan digital wallet di lingkungan kampus Universitas Bunda Mulia. Survei ini dilakukan dengan metode kuantitatif menggunakan instrumen dalam bentuk kuisioner. Tujuan dilakukannya survei awal ini untuk melihat karakteristik pengguna layanan digital wallet dan fenomena yang terjadi dalam penggunaan layanan digital wallet. Hasilnya, ditemukan fenomena menarik berkaitan dengan aspek brand loyalty dari para pengguna layanan digital wallet.

Berdasarkan hasil survei awal yang bisa dilihat pada gambar 1.1, 85\% responden pengguna layanan digital wallet menggunakan lebih dari satu layanan digital wallet. Sedangkan yang hanya menggunakan satu layanan digital wallet hanya $15 \%$ dari total keseluruhan responden. Uniknya ada $31 \%$ responden yang aktif menggunakan tiga layanan digital wallet dan ketiganya merupakan pemain besar dalam industri ini di Indonesia yaitu GOPAY, OVO dan DANA. Dari data ini terlihat jelas bahwa tigkat brand loyalty untuk pelanggan layanan digital wallet masih minim.

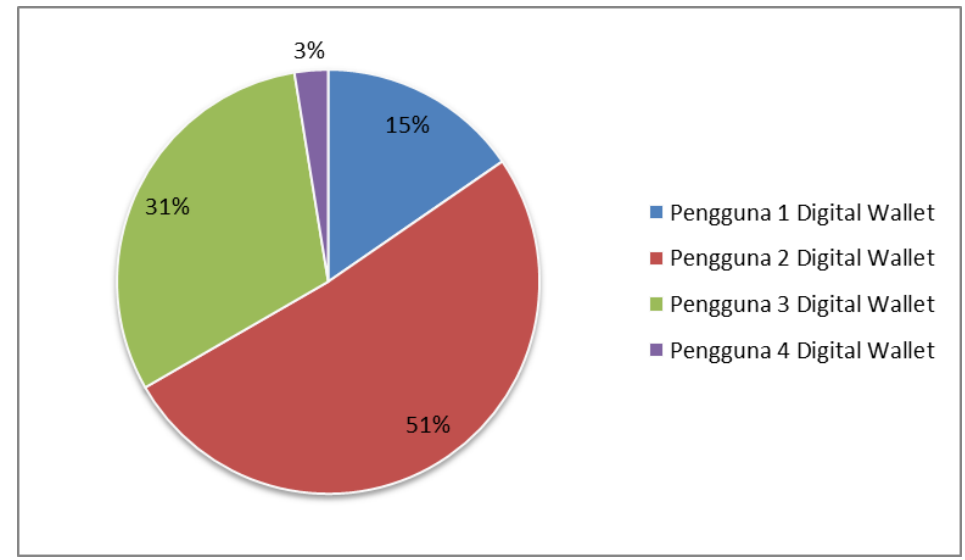

\section{Gambar 1.1 Hasil Survei Jumlah Penggunaan Aplikasi Digital Wallet (Sumber: Dokumen Pribadi, 2019)}

Melihat fenomena ini, penulis terdorong untuk melakukan penelitian untuk menganalisa pengaruh antara product usability dan cashback promotion strategy terhadap tingkat brand loyalty dari pengguna layanan digital wallet. Dalam penelitian ini, penulis memfokuskan diri kepada tiga brand digital wallet terbesar di Indonesia saat ini yaitu GOPAY, OVO dan DANA untuk menjadi objek penelitian. Tujuan penelitian ini adalah untuk 
mengetahui apakah faktor product usability dan cashback promotion memiliki pengaruh signifikan positif terhadap brand loyalty pengguna layanan digital wallet.

Hipotesis Penelitian

Penelitian ini memiliki dua variabel independen dan satu variabel dependen. Variabel independen atau variabel bebas dari penelitian ini adalah kemudahan cara pembayaran / bertransaksi atau product usability dan strategi promosi berbentuk cashback (cashback promotion). Sedangkan untuk variabel dependen atau variabel terikat dari penelitian ini adalah brand loyalty dari pelanggan layanan digital wallet. Berdasarkan hal tersebut penulis menyusun beberapa hipotesa yang dijabarkan sebagai berikut.

1. $\mathrm{H}_{0} 1=$ Product Usability dan Cashback Promotion tidak berpengaruh secara signifikan positif terhadap Brand Loyalty Layanan Digital wallet

$\mathrm{H}_{\mathrm{a}} 1$ = Product Usability dan Cashback Promotion berpengaruh secara signifikan positif terhadap Brand Loyalty Layanan Digital wallet

2. $\mathrm{H}_{0} 2=$ Product Usability tidak berpengaruh secara signifikan positif terhadap Brand Loyalty Layanan Digital wallet

$\mathrm{H}_{\mathrm{a}} 2$ = Product Usability berpengaruh secara signifikan positif terhadap Brand Loyalty Layanan Digital wallet

3. $\mathrm{H}_{0} 3=$ Cashback Promotion tidak berpengaruh secara signifikan positif terhadap Brand Loyalty Layanan Digital wallet

$\mathrm{H}_{\mathrm{a}} 3$ = Cashback Promotion berpengaruh secara signifikan positif terhadap Brand Loyalty Layanan Digital wallet

\section{Metode}

Penelitian yang akan dilakukan ini merupakan penelitian kuantitatif (menggunakan statistical analysis) dengan desain penelitian yang berbentuk correlational research yaitu penelitian yang dilakukan untuk mencari korelasi antar variabel serta ada tidaknya hubungan secara kausal antara variabel satu dengan variabel lainnya. Selain itu penelitian ini bersifat cross-sectional karena proses pengambilan data dilakukan hanya sekali saja dalam suatu periode waktu tanpa adanya perbandingan data dengan kondisi atau waktu lainnya. Teknik pengambilan data yang digunakan dalam penelitian ini adalah dengan menggunakan kuisioner dan proses pengambilan sampelnya dilakukan secara kebetulan (convenience sampling) dan acak (random sampling) dengan menargetkan para pengguna layanan digital wallet yaitu GO-PAY, OVO dan DANA yang ada di lingkungan Universitas Bunda Mulia kampus Ancol.

Penelitian ini dilakukan dengan menggunakan instrumen penelitian yaitu kuisioner. Pengembangan instrumen penelitian yang penulis lakukan adalah dengan mendesain pertanyaan-pertanyaan yang ada dalam kuisioner berdasarkan dimensi dan elemen yang berkaitan dengan variabel dependen dan variabel independen yang digunakan dalam penelitian ini (Lihat tabel 1). 
Tabel 1 Dimensi, Definisi Operasional dan Elemen Penelitian

\begin{tabular}{|c|c|c|c|}
\hline & Dimensi & Definisi Operasional & Elemen \\
\hline 1. & Brand Loyalty & $\begin{array}{l}\text { Brand loyalty merupakan } \\
\text { suatu ukuran keterkaitan } \\
\text { pelanggan kepada sebuah } \\
\text { merek. Ukuran ini mampu } \\
\text { memberikan gambaran } \\
\text { tentang mungkin tidaknya } \\
\text { seorang pelanggan beralih } \\
\text { ke merek lain yang } \\
\text { ditawarkan kompetitor. } \\
\text { (Aaker,1997) }\end{array}$ & $\begin{array}{l}\text { - } \text { Penggunaan Merek } \\
\text { - } \text { Kepuasan Terhadap } \\
\text { Merek } \\
\text { - Kesetiaan Terhadap } \\
\text { Merek } \\
\text { - Kemungkinan Untuk } \\
\text { Menggunakan Merek } \\
\text { Lain }\end{array}$ \\
\hline 2. & Product Usability & $\begin{array}{l}\text { Sejauh mana suatu produk } \\
\text { dapat digunakan oleh } \\
\text { pengguna tertentu untuk } \\
\text { mencapai target yang } \\
\text { ditetapkan dengan } \\
\text { efektivitas, efesiensi dan } \\
\text { mencapai kepuasan } \\
\text { penggunaan dalam } \\
\text { konteks tertentu. (ISO } \\
9241,1998 \text { ) }\end{array}$ & $\begin{array}{ll}\text { - } & \text { Kemudahan } \\
& \text { Penggunaan } \\
\text { - } & \text { Efisiensi Penggunaan } \\
\text { - } & \text { Mudah diingat } \\
\text { - } & \text { Kesalahan dan } \\
& \text { Keamanan (Error) } \\
\text { - } & \text { Kepuasan terhadap } \\
& \text { produk }\end{array}$ \\
\hline & $\begin{array}{l}\text { Cashback } \\
\text { Promotion }\end{array}$ & $\begin{array}{l}\text { Pengurangan harga nilai } \\
\text { jual suatu produk atau jasa } \\
\text { yang diberikan di belakang } \\
\text { berupa pengembalian } \\
\text { uang atau bentuk lainnya } \\
\text { (Nugraha, 2019) }\end{array}$ & $\begin{array}{l}\text { - } \text { Besaran Cashback } \\
\text { - Intensitas Pemberian } \\
\text { Cashback } \\
\text { - Jenis Cashback } \\
\text { - Kepuasan terhadap } \\
\text { Cashback }\end{array}$ \\
\hline
\end{tabular}

Kuisioner akan disebarkan ke para pengguna layanan digital wallet dengan target minimum 100 responden yang difokuskan berada di lingkungan kampus Universitas Bunda Mulia, Jakarta Utara.

Teknik Analisis Data

Teknik analisis data dilakukan dengan melakukan Uji Validitas, Uji Reliabilitas dan Uji Hipotesis (Analisa Koefisien Determinasi, Uji F dan Uji T) secara statistik dengan bantuan aplikasi SPSS. Uji validitas digunakan untuk mengukur ketepatan suatu item dalam kuisioner untuk memastikan item-item pada kuisioner tersebut sudah tepat dalam mengukur apa yang ingin diukur. Uji reliabilitas digunakan untuk mengetahui konsistensi alat ukur, apakah alat ukur yang digunakan dapat diandalkan dan tetap konsisten jika pengukuran tersebut diulang. (Prayatno, 2011). Analisa Koefisien Determinasi pada intinya merupakan analisa untuk mengukur seberapa jauh kemampuan model dalam menerangkan variasi variabel dependen (Hadi, 2009). Uji simultan dengan uji F bertujuan untuk mengetahui pengaruh bersama-sama variabel independen terhadap variabel dependen. Sedangkan uji parsial dengan uji T bertujuan untuk mengetahui besarnya pengaruh masing-masing variabel dependen secara individual (parsial) terhadap variabel dependen (Prayatno, 2011)

\section{Hasil dan Pembahasan}

\section{Karakteristik Responden}

Dalam tahap pelaksanaan penelitian, penulis berhasil menghimpun data sebanyak 160 responden. Jumlah ini telah memenuhi target awal penelitian yaitu sebanyak 100 responden dan lebih banyak dari tiga kali jumlah pertanyaan yaitu sebesar 78 responden $(3 \times 26$ 
pertanyaan) sesuai dengan rumus perhitungan responden minimum dalam penelitian (Hair et al, 2010). Dari 160 responden yang masuk, mereka memiliki karakteristik sebagai berikut:

- Dari keseluruhan responden, hampir seluruhnya (98.1\%) merupakan pengguna layanan digital wallet.

- Secara demografis, terdapat responden pria sebanyak $65 \%$ dan responden wanita sebanyak $35 \%$.

- $\quad 60.6 \%$ responden berusia $18-23$ tahun, $20 \%$ berusia $24-29$ tahun dan sisanya berusia diatas 30 tahun. Hanya $3 \%$ responden yang berusia dibawah 18 tahun.

- Dari keseluruhan responden, 13.8\% diantaranya menggunakan hanya 1 aplikasi digital wallet di perangkat mereka, sedangkan $86.2 \%$ sisanya menggunakan lebih dari 1 aplikasi.

- Aplikasi digital wallet yang paling sering digunakan responden adalah OVO (56.3\%) lalu diikuti Go-Pay (28.1\%) dan DANA (15.6\%)

Berdasarkan karakteristik responden diatas terlihat bahwa mayoritas masyarakat di Indonesia yang masuk ke dalam golongan generasi milenial dan generasi Z merupakan pengguna aktif dari layanan digital wallet dan sebagian besar dari mereka menggunakan lebih dari 1 layanan digital wallet. Dari sisi popularitas brand digital wallet, OVO masih menjadi brand terpopuler yang kemudian diikuti oleh Go-Pay dan DANA di belakangnya. Hal ini masih serupa dengan survey yang dilakukan penulis sebelum penelitian ini dimulai dan karakteristik ini telah sesuai dengan yang diharapkan penulis untuk menjadi data yang akan diuji.

\section{Hasil Uji Validitas dan Reliabilitas}

Hasil pengujian validitas dan reliabilitas pada seluruh data yang berhasil dihimpun menunjukan bahwa seluruh pertanyaan yang diajukan telah tepat dan sesuai untuk menjadi instrumen yang digunakan untuk mengukur setiap variabel yang ada dalam penelitian ini. Selain itu, data yang berhasil dihimpun dapat diandalkan (reliabel) dan juga konsisten dalam menggambarkan variabel.

\section{Hasil Analisa Koefisien Determinasi}

Koefisien Determinasi merupakan sebuah angka yang digunakan untuk menggambarkan seberapa besar persentase pengaruh variabel bebas yang diuji terhadap variabel terikat. Hal ini diperoleh dengan menghitung nilai $R$ Square. Dalam penelitian ini, diperoleh hasil nilai $\mathrm{R}$ Square seperti pada tabel berikut.

Tabel 2 Nilai R2 Dari Variabel Penelitian

\begin{tabular}{lcccc}
\hline Model & $\mathrm{R}$ & $\mathrm{R}$ Square & $\begin{array}{c}\text { Adjusted } \mathrm{R} \\
\text { Square }\end{array}$ & $\begin{array}{c}\text { Std Error of } \\
\text { The Estimate }\end{array}$ \\
\hline 1 & 0.773 & 0.598 & 0.593 & 2.596 \\
\hline
\end{tabular}

Berdasarkan tabel 2 diatas, terlihat bahwa nilai $\mathrm{R}$ Square dari penelitian ini adalah sebesar 0.598. Hal ini menunjukkan bahwa kedua variabel bebas dalam penelitian ini yaitu product usability dan cashback promotion memiliki pengaruh sebanyak $59.8 \%$ terhadap variabel terikat yaitu brand loyalty. Sedangkan $40.2 \%$ sisanya merupakan faktor lain yang berada diluar model penelitian yang dilakukan. Dalam hal ini dapat diartikan bahwa, faktor product usability dan cashback promotion merupakan faktor yang lebih dominan dalam mempengaruhi tingkat brand loyalty pengguna digital wallet jika dibandingkan dengan faktor lainnya, misalnya seperti faktor product security, product innovation, dan lain sebagainya. 
Hasil Uji Statistik F / Uji Hipotesis Secara Simultan

Tabel 3 Hasil Uji ANOVA (f-test)

\begin{tabular}{llrrrrr}
\hline & Model & \multicolumn{1}{c}{$\begin{array}{c}\text { Sum of } \\
\text { Squares }\end{array}$} & df & Mean Square & F & Sig \\
\hline 1 & Regression & 1544.124 & 2 & 772.062 & 114.558 & 0.000 \\
& Residual & 1037.876 & 154 & 6.739 & & \\
& Total & 2582.000 & 166 & & & \\
\hline
\end{tabular}

Tabel 3 menunjukan hasil pengujian hipotesis secara simultan untuk menguji hipotesis $\mathrm{H} 1$ untuk melihat pengaruh antara seluruh variabel bebas terhadap variabel terikat secara simultan. Dalam kasus ini, nilai $F$ hitung yang diperoleh adalah sebesar 114.558 sedangkan nilai $\mathrm{F}$ Critical yang diperoleh dari tabel $\mathrm{F}$ adalah sebesar 3.054. Dari hasil tersebut dapat disimpulkan bahwa nilai F Hitung > F Critical. Selain itu, nilai signifikan F yang diperoleh dari perhitungan adalah sebesar 0.00 (lebih kecil dari 0.05) sehingga dapat disimpulkan bahwa nilai Sig. < Alpha.

Karena nilai $F$ Hitung $>$ dari $F$ Critical dan nilai Signifikan $F<$ dari nilai Alpha maka penulis mengambil keputusan untuk menolak $\mathrm{H}_{0} 1$ dan menerima $\mathrm{H}_{1} 1$ yang menyatakan bahwa variabel Product Usability dan Cashback Promotion berpengaruh secara signifikan positif terhadap Brand Loyalty Layanan Digital Wallet secara simultan.

Hasil Uji Statistik T / Uji Hipotesis Secara Parsial

Tabel 4 Hasil Uji Koefisien (t-test)

\begin{tabular}{|c|c|c|c|c|c|c|}
\hline & & \multicolumn{2}{|c|}{$\begin{array}{l}\text { Unstandarized } \\
\text { Coefficients }\end{array}$} & \multirow{2}{*}{$\begin{array}{c}\text { Standarized } \\
\text { Coefficients } \\
\text { Beta }\end{array}$} & \multirow[b]{2}{*}{$\mathrm{t}$} & \multirow[b]{2}{*}{ Sig } \\
\hline \multicolumn{2}{|c|}{ Model } & B & Std. Error & & & \\
\hline 1 & (Constant) & -0.111 & 1.601 & & -0.070 & 0.945 \\
\hline & PRODUCT USABILITY & 0.384 & 0.062 & 0.412 & 6.227 & 0.000 \\
\hline & CASHBACK PROMOTION & 0.396 & 0.59 & 0.443 & 6.697 & 0.000 \\
\hline
\end{tabular}

Dalam tabel 4, terlihat hasil pengujian hipotesis secara parsial menggunakan t test untuk menguji hipotesis $\mathrm{H} 2$ dan $\mathrm{H} 3$ untuk melihat pengaruh antara masing-masing variabel bebas terhadap variabel terikat secara parsial. Dalam pengujian hipotesis menggunakan $t$ test, dilakukan perbandingan antara nilai $t$ hitung dengan nilai $t$ critical serta antara nilai signifikan $t$ dengan nilai alpha. Dalam kasus ini, hasil pengujian $t$ test yang diperoleh dijabarkan sebagai berikut.

Variabel Product Usability memiliki nilai t hitung sebesar 6.227 dengan nilai signifikan $t$ sebesar 0.00. Saat dibandingkan dengan nilai $t$ critical yang diperoleh dari tabel, yaitu sebesar 1.975, nilai t hitung yang diperoleh lebih besar dibanding nilai t critical. Selain itu, nilai signifikan $t$ yang diperoleh berada dibawah nilai alpha yaitu 0.05 . Karena nilai $t$ hitung $>t$ critical dan sig < alpha (0.05) maka penulis mengambil keputusan untuk menolak $\mathrm{H}_{0} 2$ dan menerima $\mathrm{H}_{1} 2$ yang menyatakan bahwa variabel Product Usability berpengaruh secara signifikan positif terhadap Brand Loyalty Layanan Digital Wallet secara parsial.

Untuk variabel Cashback Promotion, dari tabel 5.10 terlihat bahwa variabel ini memiliki nilai $t$ hitung sebesar 6.697 dengan nilai signifikan t sebesar 0.00 . Apabila dibandingkan dengan nilai $t$ critical yang diperoleh dari tabel, yaitu sebesar 1.975 , nilai t hitung yang diperoleh juga lebih besar dibanding nilai $t$ critical. Sedangkan nilai signifikan $t$ yang 
diperoleh juga berada dibawah nilai alpha yaitu 0.05 . Karena nilai $t$ hitung $>t$ critical dan sig $<$ alpha (0.05) maka penulis kembali mengambil keputusan untuk menolak $\mathrm{H}_{0} 3$ dan menerima $\mathrm{H}_{1} 3$ yang menyatakan bahwa variabel Cashback Promotion berpengaruh secara signifikan positif terhadap Brand Loyalty Layanan Digital Wallet secara parsial.

\section{Analisa Hasil Pengujian Statistik}

Melihat hasil dari seluruh pengujian hipotesis yang telah dilakukan, terlihat bahwa variabel Product Usability dan Cashback Promotion memiliki pengaruh yang sangat signifikan positif terhadap Brand Loyalty pengguna layanan Digital Wallet. Hal ini menunjukan bahwa konsumen digital wallet memiliki kecenderungan untuk lebih loyal terhadap salah satu brand apabila aplikasi digital wallet yang ditawarkan mudah untuk dipelajari dan mudah digunakan baik untuk melakukan transaksi maupun untuk melakukan top up. Apabila aplikasi yang ditawarkan justru mempersulit dan sering terjadi masalah, maka konsumen akan kekurangan respect terhadap brand sehingga beralih ke brand lainnya.

Lalu, konsumen juga akan lebih loyal terhadap brand apabila layanan digital wallet yang mereka gunakan aktif memberikan promosi dalam bentuk cashback. Dalam hal ini semakin besar nilai cashback dan semakin sering intensitas pemberian cashback maka semakin loyal pula konsumen terhadap brand tersebut. Apabila penyedia layanan mulai jarang memberikan cashback atau nilai cashback yang diberikan semakin kecil, maka konsumen cenderung akan mencari brand lain yang mampu memenuhi kebutuhan mereka.

Hal ini dapat menjadi pembelajaran bagi penyedia layanan digital wallet atau para technopreneur yang ingin memulai startup digital wallet ke depannya. Dari penelitian ini terlihat jelas bahwa apabila ingin menarik dan mempertahankan konsumen, inovasi teknologi harus terus menerus dilakukan agar perusahaan mampu mempertahankan dan meningkatkan aspek usability dari aplikasi. Semakin mudah aplikasi dapat digunakan, maka semakin sulit bagi konsumen untuk melepaskan aplikasi tersebut karena muncul rasa ketergantungan terhadap aplikasi tersebut. Terlepas dari adanya faktor lainnya, faktor product usability memang mampu menunjukkan loyalitas yang kuat bagi konsumen, contohnya seperti apabila konsumen tetap menggunakan aplikasi walaupun tidak ada program promosi, maka hal itu menunjukan faktor ini berperan penting dalam mendorong loyalitas konsumen.

Selain itu, para penyedia layanan digital wallet juga dianjurkan untuk menyeimbangkan aspek nilai dan intensitas pemberian cashback karena pada satu sisi konsumen ingin terus menerus mendapatkan benefit, namun di sisi lain perusahaan juga harus mempertahankan diri dari defisit. Pentingnya nilai dan intensitas cashback terbukti di lapangan, tepatnya saat menjelang akhir tahun 2019 dimana digital wallet besar seperti OVO, Go-Pay dan DANA mulai mengerem promosi cashback mereka dan itu membuat konsumen kebingungan dan mulai mencari alternatif digital wallet lainnya yang mampu memberikan benefit bagi mereka. Hal ini merupakan blunder yang wajib dihindari kedepannya. Para penyedia layanan diharapkan mampu secara simultan memberikan penawaran menarik terus menerus sehingga konsumen tidak berhenti untuk menggunakan aplikasi mereka. Walau begitu, cashback memang bukan satu-satunya faktor yang mampu mempengaruhi loyalitas konsumen, masih banyak konsumen yang menggunakan aplikasi walaupun tanpa adanya cashback karena melihat sisi usability seperti pada penjelasan sebelumnya.

\section{Simpulan dan Saran}

Dari penelitian ini dapat disimpulkan bahwa baik product usability dan cashback promotion memiliki pengaruh yang signifikan positif terhadap brand loyalty layanan digital wallet secara simultan maupun parsial. Hal ini membuktikan bahwa apabila aplikasi Digital Wallet mampu memudahkan konsumen dalam melakukan transaksi maka semakin tinggi pula tingkat loyalitas konsumen kepada brand digital wallet tersebut. Dengan usability yang tinggi, walaupun tidak ada promo dari brand tersebut, konsumen akan tetap memilih menggunakan layanan digital wallet dari brand tersebut. Cashback promotion yang juga berpengaruh positif terhadap brand loyalty menunjukkan pula bahwa semakin sering layanan 
digital wallet memberikan cashback dalam jumlah yang besar kepada konsumen maka konsumen akan semakin loyal untuk menggunakan layanan digital wallet tersebut.

Untuk penelitian selanjutkan, disarankan untuk menambah variabel lainnya yang juga berkaitan dengan brand loyalty seperti keamanan transaksi, keberadaan partner merchant dan lain sebagainya. Lalu dari sisi responden, disarankan untuk memfokuskan pada generasi $Z$ yang sedang mulai berkembang dan turut mendorong kemajuan bisnis digital di Indonesia saat ini. Hal ini perlu dilakukan karena penelitian mengenai generasi $Z$ masih minim.

\section{Daftar Pustaka}

Aaker, David A. (1997). Manajemen Ekuitas Merek : Memanfaatkan Nilai dari Suatu Merek. Cetakan Pertama. Jakarta : Mitra Utama.

Dikdik, M. (2019). 10 Aplikasi Pembayaran Digital yang Paling Populer Saat Ini. Retrieved from https://carisinyal.com/jenis-pembayaran-digital-populer/.

Durianto et. al. (2004). Strategi Menaklukkan Pasar Melalui Riset Ekuitas dan Perilaku Merek. Jakarta: Gramedia Pustaka Utama.

Hadi, S. 2006. Metodologi Penelitian Kuantitatif Untuk Akuntansi \& Keuangan (Pertama). Yogyakarta: Ekonisia.

Haidari, M. B., \& Tileng, K. G. (2018). Analisa Faktor-Faktor Berpengaruh pada Penggunaan Go-Pay. Jurnal Informatika dan Sistem Informasi, 4(1), 10-15.

Hair, J.F., Black, W.C., Babin, B.J. and Anderson, R.E. (2010) Multivariate Data Analysis. 7th Edition, Pearson, New York.

Karnouskos, S., dan Fraunhofer, F. (2004). "Mobile Payment: A journey Through Existing Procedures And Standardization Initiatives." Articles Original Peer-Reviewed Survey 6(4): 44-66.

Lestari, H. P. (2016). Analisis Peranan Cashback Dalam Upaya Meningkatkan Efektivitas Pengendalian Umur Piutang Pada CV. Master Mat Surabaya. Equity, 2(3).

Nielsen, J. (2003). Usability 101: Introduction to usability. Available at : http://www.nngroup.com/articles/usability-101-introduction-to-usability/

Nugraha, F. (2019). Mencatat Cashback. Retrieved September 27, 2019, from https://www.jurnal.id/id/guidebooks/mencatat-cashback.

Oktaviani, N., Astuti, W., \& Firdiansjah, A. (2019). Pengaruh Kepuasan Konsumen Terhadap Pembentukan Komitmen Pelanggan Dan e-WOM Pada Pengguna Aplikasi e-MONEY "OVO". Jurnal Manajemen dan Pemasaran Jasa, 12(1), 93-112.

Prayatno, D. 2011. SPSS Analisis Statistik Data Lebih Cepat Lebih Akurat, Yogyakarta:Medikom, h. 24.

Rahadi, D. R. (2014). Pengukuran usability sistem menggunakan use questionnaire pada aplikasi android. Jurnal Sistem Informasi, 6(1).

Refsdal, A., Solhaug, B., \& Stølen, K. (2015). Cyber-risk management. Cham: Springer.

Sarja, N. L. A. K. Y. (2016). Analisis Pengukuran Faktor Usability Sistem Informasi Konferensi Nasional Sistem dan Informatika Stikom Bali. SEMNASTEKNOMEDIA ONLINE, 4(1), 1-4. 
Sugianto, D. (2019). Terkuak, Ini Alasan OVO dan GoPay Bakar Duit Lewat Cashback. Retrieved September 27, 2019, from https://finance.detik.com/fintech/d4719215/terkuak-ini-alasan-ovo-dan-gopay-bakar-duit-lewat-cashback.

Sugiyono (2015). Metode Penelitian Kombinasi (Mix Methods). Bandung: Alfabeta

Tazkiyyaturrohmah, R. (2018). Eksistensi Uang Elektronik Sebagai Alat Transaksi Keuangan Modern. Muslim Heritage, 3(1), 23-44. 